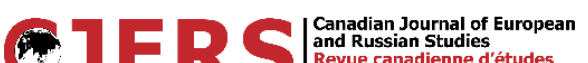 \\ CJERS $=$
}

\section{Climate Change Politics in Canada and the EU: From Carbon Democracy to a Green Deal?}

\author{
Markus Lederer ${ }^{1}$ \\ Technical University Darmstadt
}

\begin{abstract}
The idea of a green deal transforming industrialized societies' climate policies in a sustainable manner has become highly popular in various countries. This article focuses on the politics behind green deals in Canada and the EU, raising four interrelated issues. First, on a descriptive level, it addresses what has so far been achieved regarding climate policy in both polities. Second, at an analytical level, making use of the concept of carbon democracy, the study provides a theoretical explanation of why, until recently, progress has been slow in the EU and hardly visible in Canada. Third, on a prescriptive level, it argues that the notion of a green deal can be transformative and can thus provide a road to progressive climate policies. Finally, in a comparative manner, the analysis reveals Canada is still highly reluctant to enact any form of green deal, while the EU, with its notion of a 'just transition' and the set-up of a transition fund, has made important progress towards an effective and legitimate green deal that could eventually turn the EU into a green democracy.
\end{abstract}

\footnotetext{
${ }^{1}$ Markus Lederer is professor of political science with a focus on international politics at Technical University Darmstadt.
} 


\section{Introduction ${ }^{2}$}

Climate politics have changed quite dramatically over the last couple of years, but the question arises as to how truly transformative these changes have been. On the global level, the Paris Agreement of 2015 revitalized multilateral politics after the failure of the international negotiations in Copenhagen in 2009. It has also successfully kick-started new carbon governance initiatives at other levels of government (Falkner 2016). At the local level, various cities in both Canada (e.g., Vancouver, Montreal, and Toronto) and in Europe (e.g., London, Copenhagen, and Berlin) have been hailed as new spheres of authority, and associations like the C40 Cities Climate Leadership Group (C40), the Covenant of Mayors, and the Local Governments for Sustainability (ICLEI) have undertaken notable initiatives in the environmental area (Bulkeley 2014; Fuhr, Hickmann, and Kern 2018). These governance experiments have been supported by transnational actors from the non-profit and for-profit camps (Roger, Hale, and Andonova 2017). Domestic climate politics also have gained more attention on the political agenda in countries as diverse as India, Vietnam, Ethiopia, France, and the United Kingdom. And even where official reversals have occurred, most prominently in the United States (US), but also in Brazil and China, new dynamics within society or within opposition parties have sometimes become visible. These new progressive approaches, whether in the US, the European Union (EU), or Canada, have been labelled 'green deals' that aim to advance climate policy ambitions and implementation in holistic and just ways. Green deals are thus presented as a panacea for solving or at least mitigating many of the current ecological, social, economic, and political crises human society must confront.

This article focuses on the politics behind a green deal in Canada and the EU, raising four interrelated issues. First, on a descriptive level, it addresses what has so far been achieved regarding climate policy. Second, at an analytical level, making use of the concept of carbon democracy, it provides a theoretical explanation of why, until recently, progress has been slow in the EU and hardly visible in Canada. Third, on a prescriptive level, it argues that the notion of a green deal can be transformative, and can thus provide a road to progressive climate policies. Finally, in a comparative manner, the analysis reveals Canada is still highly reluctant to enact any form of green deal, while the EU, with its notion of a 'just transition' and the set-up of a transition fund, has made important progress towards an effective and legitimate green deal that could eventually turn the EU into a green democracy.

But why look at Canada and the EU and compare a country with a regional entity? First, regarding their relevance, both polities are large greenhouse gas (GHG) emitters. Canada is the ninth largest emitter in absolute terms, and fourth largest on per capita terms, within the Club of G20 countries, with almost 19 tonnes of carbon dioxide equivalent per capita $\left(\mathrm{tCO}_{2} \mathrm{e} /\right.$ capita) per year. The EU 28 is the third largest emitter in absolute terms, and the $15^{\text {th }}$ largest in annual per capita emissions within the $\mathrm{G} 20$, at about $8.07 \mathrm{tCO}_{2} \mathrm{e} /$ capita. $^{3}$ Second, both polities claim to be leaders of progressive climate change politics. The EU has long and successfully portrayed itself as a global climate leader (Wurzel, Connelly, and Liefferink 2017), while, since 2015, the Trudeau government in Canada has tried to convince the world of the greening of its policies. Nevertheless, in December, 2020 both polities were still evaluated by the Climate Action Tracker as "insufficient", although some signs of deeper change are visible, particularly within the EU (Climate Action Tracker 2020). Of course, both the EU and Canada are highly diverse polities,

\footnotetext{
${ }^{2}$ I would like to thank two anonymous reviewers as well as the editors of this special issue for extremely helpful comments on earlier drafts of this article.

${ }^{3}$ Data refers to 2017 and includes land-use; for details, see Climate Transparency (2020).
} 
and it is important to differentiate between front-runners and laggards within each (Torney 2019; Boyd and Rabe 2019). Finally, both polities are highly decentralized and are thus perfect showcases for understanding multi-level governance.

This article is structured as follows: the first part introduces the concept of 'carbon democracy' which posits that the extensive use of carbon laid the foundation for establishing democratic institutions in the first place (Mitchell 2011). Jason MacLean has already labelled Canada a carbon democracy, focusing primarily on the oil and gas industries' ability to influence current politics even with a Liberal government in power since 2015 (2018, 54). The second part of the article builds on these insights but goes beyond them by describing Canada's and the EU's emission profiles, their ambitions, and the current policy instruments deeply enmeshed in the societal and political genome of both polities. The third part elaborates on the politics of a green deal, arguing that major distributive changes and some forms of compensation will be needed as the green deal will not always create win-win solutions, particularly not in the short run. The analysis shows that the EU is slowly moving towards a green democracy, whereas progress is much slower in Canada. The conclusion summarizes the argument and identifies possible future research avenues.

\section{The Concept of Carbon Democracy}

Decarbonization is possible, and at least in the medium to long run it reduces private and social costs when compared to a business-as-usual scenario (Stern 2015; The New Climate Economy 2018). Why then has progress so far been rather slow? To answer this question, we have to look at how politics affects efforts to pursue green transformations. The literature on climate politics has advanced various explanations including veto-players (Ike 2020), the capitalist system (Brand and Wissen 2017), domestic politics (Sprinz and Weiß 2001), national-subnational interlinkages (Balthasar, Schreurs, and Varone 2019), and, most recently, energy cultures (Stephenson, Sovacool, and Inderberg 2021). The concept of carbon democracy nicely complements these explanations by focusing on the materiality of carbon and the repercussions its rising use has had for the development of specific political systems. Theoretically, the argument advanced is in line with historical institutionalism with its strong focus on path-dependencies. It also takes up elements of more recent materialist readings that have identified the strong influence of specific uses of energy on societies and politics (Morris 2015 regarding values; Smil 2018 regarding civilizations).

Timothy Mitchell's book, Carbon Democracy: Political Power in the Age of Oil (2011), makes the simple but important point that, historically, carbon energy and democratic politics are closely interlinked, and that changes in how we made use of energy allowed and even determined the way mass politics evolved in Western Europe and North America $(2011,14)$. Not only has the burning of abundant and low-cost carbon in the form of coal, oil, and gas fueled accelerated economic growth, but also the extraction, transportation, and refinement of fossil fuels have shaped sociotechnical systems that have become very influential politically. This started with the massive extraction and use of coal that enabled large-scale manufacturing, modern cities, and those forces that pushed for democracy $(2011,8)$. Hence, democratic claims had a much higher chance to be realized in countries where large parts of the workforce were involved in digging up and transporting coal, as well as providing a whole new infrastructure for its use. Workers thus derived power from how energy extraction, transportation, and use were organized. This could be translated into alliances, and carbon could thus "assemble political agency, by employing the 
ability to slow, disrupt or cut off its supply" $(2011,19)$. In short, the use of coal allowed workers to become a highly political force and this was, Mitchell argues, more important politically than class culture, ideology, or organization $(2011,27)$.

In the following article, the concept of carbon democracy is used as a prism to interpret the evolution of climate policy-making in Canada and the EU, and to understand why progress in moving away from fossil fuels has been rather limited. This approach neither neglects the role of specific actors, nor denies the influence of capitalism. Rather, it goes one step further and analyzes the strong role of the carbon centered, socio-technical systems found in both polities. Three aspects will merit specific attention. First, the influence that the development of large infrastructures for energy extraction, production, transportation, and consumption have had in empowering some actors, as well as practices, and not others. Second, that these actors are represented in specific sectors or regions with consequences for policy-making and specific political structures. And third, that the particular context of infrastructures, actors, and sectors has given rise to a carbon centered worldview that has underpinned and strengthened carbon democracy.

\section{Carbon Democracy at Work: Comparing the Status-Quo of Climate Politics in Canada and the EU}

This section provides a short overview of climate politics in Canada and the EU, focusing particularly on their current emission profiles and policies. In the second part, these developments are examined by taking the concept of carbon democracy into account.

\section{Describing the Status Quo: Emission Profiles and Policies in Canada}

Canada's climate policy-making has seen various ups and downs and has been rather inconsistent, particularly regarding its international aspirations and domestic actions (Macunias and de Lassus Saint-Geniès 2018, 2). In the 1980s and 1990s, Canada was one of the most active countries pushing for international climate action, but divergence between its international stance and domestic climate legislation became visible after the turn of the century (Macunias and de Lassus Saint-Geniès 2018). Starting in 2006, when Stephen Harper became prime minister, the country's international position on climate action increasingly aligned with its domestic policies, such that on neither front much happened $(2018,6)$. Canada was in no way close to fulfilling its Kyoto target of reducing its GHG emissions by six percent of 1990 levels by 2012; rather its emissions in 2008 were 24.1 percent higher than the 1990 base year. It was thus no surprise that Canada withdrew from the Kyoto Protocol in 2011.

After the Trudeau government won the election in 2015, Canada became an active negotiator during the climate negotiations of 2015 that generated the Paris Agreement, mirroring the position of the US (MacNeil and Paterson 2016). For example, Environment and Climate Change Minister Catherine McKenna said after the meeting that "Canada is back" (King 2015). In its Nationally Determined Contribution (NDC), Canada promised to reduce its GHG emissions by 17 percent by 2020, and 30 percent by 2030, against a 2005 base year. However, its own projections show that it will be hard to achieve these goals (Government of Canada 2015; 2019). Currently GHG emissions are 17 percent higher than they were in 1990, more or less at the same level as they were in 2005. In short "despite a change in tone in Paris, Trudeau opted to keep the national GHG emission reduction targets set by the Harper government, which aligned with US targets" (Boyd 
and Rabe 2019, 242). The Canadian government has officially distanced itself from Donald Trump's anti-Paris Agreement rhetoric, but on a per capita basis Canadian emissions are even slightly higher than those of the US (Climate Transparency 2020). Partially thanks to fracking (which has other highly problematic environmental impacts) the build-up of renewables, and reduction in the use of coal, the US has been able reduce its emissions considerably over the last ten years.

As various authors have pointed out (Schreurs 2011; Boyd and Rabe 2019, 252f; Boyd 2019), there are significant differences between the Canadian provinces. Alberta alone is responsible for about a third of Canada's GHG emissions, and emissions from Alberta and Saskatchewan are still increasing. Ontario and Quebéc, meanwhile, have managed to reduce their emissions quite substantially and are cooperating with progressive US states. They are also adopting best practices from the US. To fulfill its Paris Agreement obligations, the Canadian government launched the Pan-Canadian Framework (PCF) on Clean Growth and Climate Change in 2016 and the Greenhouse Gas Pollution Pricing Act in 2018. The PCF is highly flexible in allowing the provinces leeway on how to tackle climate change as long as something is happening that puts a price on carbon. Thus, British Columbia (BC) and Alberta introduced a $\mathrm{CO}_{2}$ tax, whereas Ontario and Quebéc started to set up an emission trading system (ETS), which Ontario abandoned in 2018. In April 2019, the federal government introduced a carbon tax on fossil fuels in four provinces (Ontario, Manitoba, New Brunswick, and Saskatchewan) after the provincial governments did not establish legislation to reduce greenhouse gas emissions.

Evaluating Canada's 2030 pledge, the International Monetary Fund (IMF) claims the country's current plan will not be sufficient. Additionally, a recent World Bank report on carbon pricing calculated that to achieve the Paris goal, Canada's $\mathrm{CO}_{2}$ tax would need to increase from 15 Canadian dollars per tonne of $\mathrm{CO}_{2}$ today, to between 75 and 150 Canadian dollars per tonnes in 2030 (2019, 19). According to the dominating perception, Canada is backtracking on its Paris Agreement commitments and is "falling back on the centrality of its bilateral relationships with the United States and contending that it could only consider acting if America was moving in step" (Boyd and Rabe 2019, 254-255). Currently, deep decarbonization is not on the federal government's agenda. The country has introduced some new policies but will most likely miss its own NDC target, which was not very ambitious to begin with (Kuramochi et al. 2019, 32).

\section{Describing the Status Quo: Emission Profiles and Policies in the European Union}

If one compares the EU's domestic track record with that of Canada, the EU is doing better, having built up "the world's most advanced and comprehensive regulatory frameworks, encompassing both EU-wide policies and targets to be achieved by the member states" (Delreux and Ohler 2019, 2). The EU has overachieved its Kyoto target of eight percent below $1990 \mathrm{CO}_{2}$ emission levels during the first commitment period 2008-2012 by delivering a reduction of 12 percent. The bloc has also fulfilled its pledge for 2020 (20 percent below 1990 levels). The main reason for the EU's success so far, besides the financial crisis and the de-industrialization of some parts of Eastern Germany, has been a tremendous increase in the use of renewable energy sources: between 2005 and 2015, there was a 71 percent increase of renewable energy capacity within the EU.

Still, some serious problems persist. In 2017, there was a 0.6 percent increase of GHG emissions within the EU, even within those sectors covered by the EU ETS. This was due to an increase in the use of lignite for power generation. In 2018, there was a reduction of emissions by 2.1 percent, but this happened almost solely due to changes in the power sector, and the transport sector 
witnessed a slight increase. In 2020, the slowdown due to the various pandemic lock-downs has led to further and substantial decreases in GHG emissions, but it is questionable whether these will be permanent (for a more positive reading, see Schreurs and Schott 2020 this issue). Of course, the EU is not a monolithic bloc. Some countries are doing more than others; for example, Sweden and Denmark, according to the 2019 New Climate Institute's Climate Change Performance Index, are the two global front-runners regarding their path toward the Paris Agreement's targets (Burck et al. 2019). Countries like Estonia, Bulgaria, and Poland, on the other hand, are doing much worse. In the EU, the European ETS has so far been the main instrument in mitigating climate change; it covers about 40 percent of the EU's emissions in six sectors and in about 11,000 installations. Non-ETS sectors like agriculture, transport (except air transport), or buildings are in the domain of the member states, with each one having a specific target. The EU ETS has been perceived as a success, as it has not only facilitated the reduction of GHG emissions, but has been more successful in those industries that are covered by the scheme than those that are not (Ellerman, Marcantonini and Zaklan 2015). Additionally, the ETS has not reduced competitiveness of impacted companies (Joltreau and Sommerfeld 2019). The EU ETS, which was reformed in 2018 to avoid a growing surplus of emission rights (Wettestad and Jevnaker 2019; EU 2018), will also lead to further reductions. Its phase four, beginning in 2021, includes a yearly reduction of the cap of 2.2 percent (Oberthür 2019, 19). Nevertheless, problems are still visible, and they have to do with the various exceptions for specific industries and the grandfathering of a still large amount of emission rights. Furthermore, the hard nuts to crack - transport and buildings - have not yet been included, and only recently has much progress has been achieved in these sectors (Delreux and Ohler 2019, 11).

\section{Interpreting and Comparing the Status Quo: Carbon Democracy at Work}

The EU and Canada have taken divergent paths and it is evident that the former has produced more progressive climate policy-making. Nevertheless, both polities have historically featured the major characteristics of carbon democracy. In Canada and the EU (or, more historically correctly, in its member states) broader mass participation in politics was influenced by the extensive use of first coal and later oil. During the "great acceleration" (Steffen et al. 2015) after the end of World War II, Canada and Europe extensively relied on the socio-technological system of fossil fuels, and they partially still do. In both polities, it was not only that economic growth depended on the burning of coal and oil, but a huge fossil fuel energy infrastructure was also formed. This infrastructure supported and strengthened powerful fossil fuel-based sectors, primarily energy companies in Canada and the automotive sector in Europe, that came to dominate their economies and fed into the development of a worldview that entrenched the use of fossil fuels.

First, regarding energy extraction, production, transportation, and consumption, Canada and the EU have both strongly relied on the digging up and burning of coal, oil, and gas. In both regions, infrastructures have been set up that have locked in the use of fossil fuels for the next generation. This has been most evident in the discussions about new pipelines. For Canada, the "pipelines for Paris" suggestion (MacLean 2018) implied that the Paris Agreement could only gain enough political support in Canada if its ratification would not lead to a shut-down of pipelines. This might not have increased the government's popularity, particularly in Alberta, but it certainly entrenched the power of the fossil fuel industry. Former Alberta Premiere Alison Redford stated, "Alberta's oil sands are the lifeblood of our economy." Indeed, if realized, the GHG emissions of the Pacific Northwest Liquid Natural Gas project would make up about 10 percent of Canada's remaining carbon budget if calculated on a per-capita emissions basis $(2018,52)$. Even more worrisome, the upstream GHG emissions caused by the Trans Mountain pipeline, which the government purchased in 2018 and which is estimated to work over a period of 50 years, will by itself consume 
about 83 percent of Canada's share of its carbon budget if we take the Paris Agreement's more lenient target of two degrees Celsius as a benchmark $\left(100\right.$ percent if a $1.5^{\circ} \mathrm{C}$ target is taken) $(2018$, 58). Bill McKibben (2020) thus claimed that "Canada, which is 0.5 percent of the planet's population, plans to use up nearly a third of the planet's remaining carbon budget." Furthermore, the Canadian government is, all rhetorical claims withstanding, deeply embedded in the fossil fuel age, as demonstrated by the various direct and indirect subsidies of about 40 billion dollars to oil and gas in 2015 (Green 2019).

For the EU, Nord Stream 2 is to transport natural gas directly from Russia to Germany. This will at first reduce Germany's, and thus the EU's, carbon emissions, as natural gas will primarily replace lignite. But in the medium to long run, it will have serious environmental impacts in Russia, and will lock the EU into a new infrastructure set to deliver 55 billion cubic metres of natural gas that will produce about 106 million tonnes of $\mathrm{CO}_{2}$ - the equivalent of the annual emissions of the Czech Republic (Stoczkiewicz 2017). Similar to Canada, though on a smaller scale overall, the EU is thus partially locking-in its dependence on natural gas. As for coal, in the PCF Canada committed itself to a national phase out by 2030, although some leeway is provided on the provincial level (Boyd and Rabe 2019, 248). Within the EU, Portugal, Greece, Hungary, France, Germany, and now even Poland announced the phaseout of coal. However, the closing of all coal fired power plants will most likely not happen before 2038 when Germany and Poland have finished their respective phaseouts.

Second, Canada and the EU still have sectors that are hard to green, which has given rise to a variety of veto-players. For Canada, this is evident in the case of utilities and energy companies, including the huge field of mining and extraction. These sectors represent a form of "prairie capitalism" that Richards and Pratts (1979) identified as a trend for Canada in some Western provinces more than four decades ago and that Kellogg (2015) recently 'revisited' for the oil and bitumen industries. The argument behind prairie capitalism is analogous to carbon democracy in that it stresses the important influence of large-scale ownership of specific extractive assets. The claim of prairie capitalism is that it is not foreign capital that advances capitalist practices, for example in Alberta's bitumen industry, but rather a regional bourgeoisie, and that therefore Canada should not be understood as being part of a colonial periphery but rather of the capitalist center. Canada exported fossil fuels worth 134 billion Canadian dollars in 2019 (Government of Canada 2020) and the export-oriented agricultural sector is also highly dependent on fossil fuels. These exports go primarily to the US market, leading to a high level of vulnerability to what happens there, but these industries are largely owned by Canadians. A restructuring of these sectors would be very cost intensive (Boyd and Rabe 2019, 242) and would impact the social fabric of Canadian capitalism. But it is not only the 'bourgeoisie' that is profiting from Canada's carbon democracy; unions are particularly strong in the fossil fuel-dependent sectors. Workers in these sectors often enjoy wages far above average and are reluctant to give up their privileged position (MacArthur et al. 2020, 5).

In the EU, the fossil fuel sector is less entrenched than in Canada, but industrial policy is strongly influenced by companies and unions which depend on fossil fuels; this starts with Airbus and includes the automotive sector with its strong union culture. Furthermore, the strong welfare state in both polities, and the corporatist politics in the mentioned industries, make ambitious reforms with redistributive effects hard to implement (MacArthur et al. 2020). Both Canada and the EU strongly rely on economic growth, and any policy that does not take this into account might face massive opposition. In Europe, this became evident with France's 'yellow vest movement' opposing President Macron's increase of gas prices in 2019. Also, in late 2019 the German right- 
wing party Alternative für Deutschland (AfD) announced its intention to contest the financing of renewable energy and any plans to further reduce GHG emissions. Climate thus became the third major topic of the party.

In Canada and the EU, these policies also face strong subnational/national actors that have substantially entrenched veto positions. In both polities the 'federal' level has only marginal competences to actually bring change to the socio-technical infrastructure in place. For example, Alberta in Canada and Poland in the EU can be considered spoilers of progressive climate change policies. These actors cannot simply be sidelined. Alberta strongly depends on revenues from the oil and gas industry which is responsible for over a third of Alberta's emissions (Boyd 2019, 2). Despite the fact that Alberta is a leader in installing wind power installations, with an installed wind energy capacity of 1,685 Mega Watt (CanWEA 2020), it is a "reluctant actor" that moves only when external pressure, usually from the US, is present (Boyd 2019, 2; MacDonald and VanNijnatten 2010). Thus, within Canada's strong federalist tradition, "Ottawa has limited capacity to control or direct Canadian climate policy" (MacNeil and Paterson 2016, 556), and it is particularly at the provincial level that more progressive action is being held back.

Poland, which depends on coal for its power sector, has emerged as the main spoiler of climate change policies in the EU. The EU has repeatedly compromised on its policy frameworks due to Polish pressure (Skjærseth 2018). The EU might have some leeway on climate policies but is historically lacking the power to regulate energy issues (Szarka 2016) and has only recently started to engage in regulating traffic. The EU 2030 Framework also shows that the European Commission could not set binding energy efficiency or renewable energy targets on the member states, although it could strengthen procedural obligations of member states regarding their energy and climate plans (Oberthür 2019, 24).

Finally, Canada and the EU are carbon democracies not only in that both polities rely on energy in a material sense, but also in their worldviews (for a general debate on worldviews and climate change, particularly mobility, see Chuang, Manley, and Petersen 2020; Sovacool and Griffiths 2020). Canadians' and Europeans' respective identities are to some extent shaped by a tradition of resource extraction and high mobility. In Canada, this is part of the pioneer mentality, where nature is understood as a "hinterland" whose purpose it is to provide goods for its citizens, while European populations might perceive of nature rather as countryside that is also available for human use (Dalby 2019, 103). In both polities, a culture of high mobility has evolved that relies on individualized transport. In Canada and the EU, legislation has introduced higher emission standards, and both polities have started to subsidize electric mobility, fostering some discussions on smarter mobility (Barr 2018), but neither has so far started to rethink transport more fundamentally.

\section{Transforming Carbon Democracies Through Green Deals?}

Canada and the EU are carbon democracies, but could this be changed through domestic pressure, as foreseen in the Paris Agreement (Falkner 2016)? After all, various actors within civil society are pushing for more progressive climate policies, resonating with a more general attitude within the population. For example, in Canada, more than half of the population supports the introduction of market-based mechanisms to stop climate change and this holds true even for provinces that have historically been reluctant on mitigation actions (Pew Research Center 2017; Mildenberger and Lachapelle 2019). Furthermore, the youth activist Fridays for Future movements are active in 
both polities even though they have resonated more within the EU. Greta Thunberg was invited by Ursula von der Leyen, president of the EU Commission, when von der Leyen presented the EU's new climate law in March 2020. Thunberg, nevertheless, criticized the EU's position as a "surrender" because it failed to keep up with the 1.5 degree target of the Paris Agreement (BBC 2020). Similar to the student protests of the 1960s which called for democratizing Western societies, the current youth movement calling for more radical climate policies might have a chance to actually make an impact (Marquardt 2020). Fridays for Future is an indicator that climate change has become politicized in the sense that conflicts in this policy field are becoming more intense and visible (Schattschneider 1960; Hutter and Grande 2014). This implies that climate is gaining in salience with more actors being involved, more polarization in viewpoints, and more alternatives being developed (for a discussion of these elements of politicization, see Grande, Schwarzbözl, and Fatke 2019; Hoeglinger 2016).

Many alternatives are currently being envisioned under the term 'green deal', a label which refers to Franklin Delano Roosevelt's 'New Deal' which unleashed various public works and investment programs in the US between 1933 and 1939 to counter the effects of the Great Depression, when the unemployment rate ballooned to 25 percent. This governmental involvement in the US economy was unprecedented, and it made the government the largest employer in the country. Furthermore, Roosevelt's New Deal also increased the power of the federal government in relation to the states (Patterson 1969). The metaphor of the New Deal is today advanced by very different camps. In academia, for example, there is a group of scholars who argue that a green deal must be radically transformative, and to be successful it will have to overcome capitalism (Pettifor 2019; Klein 2019). Others have stressed that a green deal could be part of ecological modernization and a green economy (e.g. Jänicke 2012; Pahle, Pachauri, and Steinbacher 2016; UNEP 2011; Rifkin 2019).

Politically, the notion of a green deal was most prominently promoted by Democratic Congresswoman Alexandria Ocasio-Cortez in the US, who became a figurehead for progressive climate policies in America in 2018. She builds on debates that had been around, at least within the Democratic Party, since 2006 (Bang and Schreurs 2011) and that at the same time also had gained a lot of traction in some parts of the Labour Party in the UK. In the US, the green deal offers to provide a political, as well as economic or societal, answer to the climate problem. Although President Biden was hesitant to endorse the notion of a green deal during the campaign, his "Plan for a Clean Energy Revolution and Environmental Justice" contains many of the major economic, social, and ecological elements of what the proponents of the green deal have demanded, such as a massive roll-out of new energy infrastructures (Biden 2020). Hence, the US example shows that climate issues are no longer just another environmental problem, but rather a challenge to how the economic system is structured. Furthermore, proponents have a very strong focus on social justice and are trying to reach out to blue-collar workers. How are these ideas taken up in Canada and the EU, and do they have a chance to provide an alternative to carbon democracy?

\section{The Green Deal in Canada: A Variety of Bottom-Up Movements}

In Canada, the idea of a green deal has been embraced by various civil society organizations (e.g., Greenpeace, North 99) as well as by local communities and Indigenous groups who are pushing for transformative policies that would end Canada's dependence on fossil fuels (MacArthur et al. 2020). In 2019, many grassroots initiatives which were opposed to the North American Free Trade Association (NAFTA) have turned their attention to environmental issues and started to campaign for a 'New Green Deal' (Coalition for a Green New Deal 2019). This campaign serves as a rallying 
cry that unites various political agendas. For example, the movement of "The Pact for a Green New Deal" was developed through town hall meetings which gathered a diverse set of demands ranging from Indigenous rights to green infrastructures. The resulting list was labelled a "Green New Deal". The movement for a green deal is particularly strong in Quebéc, where a "Pacte pour le transition" was introduced and signed by more than 285,000 people in April 2020 (Shields 2019). At the federal level, Member of Parliament Peter Julian submitted a motion for a "Green New Deal for Canada" in December 2019, a legislative initiative advocating for a green deal in Canada which stressed the notion of a just transition (Julian 2020). What is evident is that in all statements and formulations of the broader movement, the issue of social justice is a major demand and the notions of Indigenous knowledge, as well as climate justice, are particularly stressed (The Council of Canadians 2019).

Evaluating the various attempts to bring about a green deal in Canada, Jessica Green (2019) suggests that so far it "is more aspiration than legislation. But the momentum for decisive action on climate change is growing." One can thus conclude that the idea of a green deal in Canada is an attempt to move beyond carbon democracy from the bottom up, building on grassroots movements and stressing justice as well as local and Indigenous forms of knowledge (see also MacArthur et al. 2020). A new worldview is being promoted, but there is still not enough momentum for a new socio-technical infrastructure to evolve. Neither are the existing power structures of the fossil fuel industry - particularly the energy sector - being replaced, nor are the veto positions of fossil fuel dependent provinces being challenged. At least for the foreseeable future, it thus seems unlikely that these bottom-up processes will evolve into a game changer to Canada's carbon democracy and prairie capitalism.

\section{The Green Deal in the EU: Top-Down Approaches in Times of COVID-19}

In Europe, the idea of a green deal has been advanced in a top-down fashion more than it has in Canada. The concept was promoted by the EU Commission, which announced that Europe will be the first carbon-neutral continent and which promised to "transform the EU into a fair and prosperous society, with a modern, resource-efficient and competitive economy where there are no net emissions of greenhouse gases in 2050 and where economic growth is decoupled from resource use" (European Commission 2019, 2). The Commission's president, von der Leyen, announced a plan worth one trillion euros that over a period of 10 years will massively restructure Europe's industry toward decarbonization. The first objective was initially set to 50 percent reduction of the EU's emissions by 2030 (taking 1990 as the base year); however, this target was increased to 55 percent in December 2020 by the European Council in order to provide new momentum to the stagnant European economy. The green deal is also much more ambitious in its scope compared to former policy announcements, as it focuses not only on carbon pricing through the EU ETS, potentially supported by a carbon border tax to avoid leakage, but also on sustainable investment, e.g., in the fields of buildings, mobility, industrial policy, and a just transition (European Commission 2019). In particular, the notion of a just transition fund of about 100 billion euros to compensate those regions and sectors within Europe that lose out from decarbonization and to counterbalance adverse distributional effects, potentially through compensation mechanisms, has been perceived as an innovative way to get countries like Poland on board (Claeys, Tagliapietra, and Zachmann 2019, 15f).

The EU's green deal has been criticized for the fact that not much of the money is actually new or additional but rather represents a reshuffling of existing funds, generating only 7.5 billion euros in new commitments (Varoufakis and Adler 2020). It is also highly questionable how green the 
contributions really are, such as those regarding farm subsidies. Furthermore, most of the money is supposed to come from private-sector investments, but the private sector is still under-investing in green technologies. To reach the targets of the green deal, about 25 percent of all new investments will have to go into sustainable technologies, up from only 12 percent now (Geinitz 2020). Finally, the EU reached an agreement on its future budget for 2020-2027, which includes a COVID-19 recovery fund and which foresees 30 percent of allocated resources being used to finance various aspects of the EU's climate objectives. However, so far in all G20 countries the money spent in the context of COVID-19 has supported high-carbon economic production, although the EU is the polity investing most in low-carbon production measures (UNEP 2020, 38).

Despite numerous challenges, the overall outlook is positive. First, the green deal will lead to some climate mainstreaming as is already visible with the EU stability pact, where - before the COVID19 crisis and the factual cancellation of the pact - the idea was floated that climate measures would not count as fiscal deficits. This is relevant as it allows EU member states to invest more in sustainable technologies and practices without having to fear that austerity measures from the EU Commission will follow. The green deal also targets the common agricultural policy and infrastructure investments that so far have not been front-runners of decarbonization, thus developing a strong multi-sectoral component.

Second, the European measures might have some leverage on the member states, which is not only true for potential buy-in by Poland but also due to provisions of ambitious parameters for the frontrunners. For example, the German energy transition might get a necessary boost through tougher European regulations (Löschel 2020). Other players who tried to stop the Commission's work on the green deal, like the Czech president Babis, were simply sidelined and could not stop the deal nor the recovery fund (Oroschakoff and Mathiesen 2020).

Third, the green deal is supported by the European Central Bank, and some policy-makers have brought up the idea of green bonds which would, for the first time, provide the EU with revenues independent from the member states (Taylor 2021). Likewise, the European Investment Bank will continue to restructure its financing to make it greener. Similarly, the green deal is going beyond the piecemeal attempts that characterized earlier European approaches (Harvey and Rankin 2020). The green deal will be particularly important for European clean-tech companies which need to scale up within the larger European market in order to be on an equal footing with the competitors in the US and China that often underprice European companies due to having gained experiences in larger domestic markets (Claeys, Tagliapietra, and Zachmann 2019, 14).

The green deal could, therefore, evolve as a first step for the EU to move beyond the characteristics of a carbon democracy. The EU member states' phase out of extracting and burning coal, and the concurrent investment in renewable energies, allows the build-up of a new socio-technical infrastructure that is no longer based on fossil fuels. Important sectors like the European car industry and even whole countries like Poland are now being pressured by the European Commission and civil society to make the changes they had long avoided (Oroschakoff and Mathiesen 2020). A new momentum has been created that will make obstructive policy-making much harder to succeed. Finally, with the attempt to integrate progressive climate policies across the whole spectrum, and addressing recalcitrant sectors like traffic, agriculture and building, the EU can no longer be criticized for shallow green-washing. 


\section{Conclusion: From Carbon to Green Democracy?}

The gist of this article can be summarized in two arguments. First, Greta Thunberg's warning at the Davos World Economic Forum in January 2019 that "the house is on fire" came right on time. Indeed, the science showing the negative impacts on our planet of anthropogenic climate change is extremely disturbing (IPCC 2018). As this article has argued, contrary to official claims, neither Canada nor the EU has so far been a successful firefighter. The socio-technical infrastructure behind the extraction, transportation, and consumption of fossil fuels is still to a large extent structuring their economies, societies, and politics in profound ways. Carbon democracy has been deeply entrenched in both polities. Too often policy and academic debates on how the climate problem can be solved are framing the issue as another environmental disturbance that needs a technical solution, but ignoring the deep-seated entrenchment of carbon democracy.

Second, not all hope is lost. Fridays for Future and other civil society movements are contributing to a strong politicization of climate change. And at least for the EU, the politicization has found a rallying cry in the idea of a European green deal. This could lead to what Meadowcraft and others have labelled a "green state" (Bäckstrand and Kronsell 2015; Duit, Feindt, and Meadowcroft 2016; Meadowcroft 2012). However, for Canada it is evident that much has to happen to overcome the deep-seated practices of prairie capitalism and carbon democracy. As Canada has traditionally aligned its climate policy with that of the US, there is hope that the government may again align its policies with the new US administration that plans to engage more constructively in global climate talks and to change some elements of its fossil fuel socio-economic infrastructure. Whether the more positive evaluation of the EU is due to the fact that the EU institutions are more insulated from public pressure, and thus can force decarbonization more strongly than can their counterparts in a country like Canada, is an open question that merits further research. In conclusion, decarbonization and the attempt to leave the socio-technical infrastructure of our carbon democracies behind us have slowly evolved into a political and social project that could lead to the much-needed green transformation. 


\section{REFERENCES}

Bäckstrand, Karin, and Anika Kronsell, eds. 2015. Rethinking the Green State: Environmental governance towards climate and sustainability transitions. London: Routledge.

Balthasar, Andreas, Miranda A. Schreurs, and Frédéric Varone. 2019. "Energy Transition in Europe and the United States: Policy Entrepreneurs and Veto Players in Federalist Systems." The Journal of Environment \& Development 29 (1): 3-25. doi: 10.1177/1070496519887489.

Bang, Guri and Miranda A. Schreurs, 2011. "A Green New Deal: Framing U.S. Climate Leadership." In The European Union as a Leader in International Climate Change Politics, edited by Rüdiger K.W. Wurzel and James Connelly, 235-251. London: Routledge.

Barr, Stewart. 2018. "Personal mobility and climate change." WIREs Climate Change 9 (5): e542. doi: $10.1002 /$ wcc.542.

BBC. 2020. "Greta Thunberg brands EU's new climate law 'surrender'." BBC, March 4, 2020. Accessed April 1, 2020. https://www.bbc.com/news/world-europe-51736134.

Biden, Joe. 2020. "The Biden Plan For A Clean Energy Revolution and Envrionmental Justice." Accessed April 1, 2021. https://joebiden.com/climate-plan/.

Boyd, Brendan. 2019. "A Province under Pressure: Climate Change Policy in Alberta." Canadian Journal of Political Science 52 (1): 183-199. doi: 10.1017/S0008423918000410.

Boyd, Brendan, and Barry Rabe. 2019. "Whither Canadian Climate Policy in the Trump Era?” In Canada-US Relations: Sovereignty or Shared Institutions?, edited by David Carment and Christopher Sands, 239-260. Cham: Springer International Publishing.

Brand, Ulrich, and Markus Wissen. 2017. Imperiale Lebensweise. Zur Ausbeutung von Mensch und Natur im globalen Kapitalismus. München: Okeom.

Bulkeley, Harriet. 2014. “Climate change and urban governance: a new politics?” In Routledge International Handbook of Social and Environmental Change, edited by Stewart Lockie, David A. Sonnenfeld, and Dana R. Fisher, 157-169. London: Routledge.

Burck, Jan, Ursula Hagen, N. Höhne, Leonardo Nascimento, and Christoph Bals. 2019. "Climate Change Performance Index. Results 2020.” Cologne, Bonn, Beirut: New Climate Institute, Germanwatch, CAN.

CanWEA (Canadian Wind Energy Association). 2020. "Wind energy in Alberta." CanWEA. Accessed December 18, 2020. https://canwea.ca/wind-energy/alberta/.

Chuang, Frank, Ed Manley, and Arthur Petersen. 2020. "The role of worldviews in the governance of sustainable mobility." Proceedings of the National Academy of Sciences 117 (8): 4034. doi: 10.1073/pnas.1916936117.

Claeys, Grégory, Simone Tagliapietra, and Georg Zachmann. 2019. "How to make the European Green Deal work.” Bruegel Policy Contribution No. 14. Brussels: Bruegel. 
Climate Action Tracker. 2020. "Countries." Accessed December 15, 2020. https://climateactiontracker.org/countries/.

Climate Transparency. 2020. "Countries." Accessed December 15, 2020. https://www.climatetransparency.org/countries.

Coalition for a Green New Deal. 2019. "What did we hear at The Pact for a Green New Deal Town Halls?” Accessed January 4, 2021. https://act.greennewdealcanada.ca/what-we-heard/.

Dalby, Simon. 2019. "Canadian geopolitical culture: Climate change and sustainability. The Canadian Geographer 63 (1): 100-111. doi: 10.1111/cag.12472.

Delreux, Tom, and Frauke Ohler. 2019. "Climate Policy in European Union Politics," edited by Oxford Research Encyclopedias.

Duit, Andreas, Peter H. Feindt, and James Meadowcroft. 2016. "Greening Leviathan: The rise of the environmental state?" Environmental Politics 25 (1): 1-23.

Ellerman, A. Denny, Claudio Marcantonini, and Aleksandar Zaklan. 2015. "The European Union Emissions Trading System: Ten Years and Counting." Review of Environmental Economics and Policy 10 (1): 89-107. doi: 10.1093/reep/rev014.

European Union (EU). 2018. "Directive (EU) 2018/ 410 of the European Parliament and of the Council.” March 14, 2018. Brussels: European Union.

European Commission. 2019. "Communication from the Commission to the European Parliament, The European Council, the Council, the European Economic and Social Committee and the Committee of Regions: The European Green Deal.” Brussels: European Commission.

Falkner, Robert. 2016. "The Paris Agreement and the new logic of international climate politics." International Affairs 92 (5): 1107-1125.

Fuhr, Harald, Thomas Hickmann, and Kristine Kern. 2018. "The role of cities in multi-level climate governance: Local climate policies and the $1.5^{\circ} \mathrm{C}$ target." Current Opinion in Environmental Sustainability 30: 1-6. doi: 10.1016/j.cosust.2017.10.006.

Geinitz, Christian. 2020. "Klimavorreiter scheitern am EU-Ziel.” Frankfurter Allgemeine Zeitung, February 25, 2020. https://zeitung.faz.net/faz/wirtschaft/2020-0225/bdd240acdbc91dbf5a23905ecf9f14e6/?GEPC=s5.

Government of Canada. 2015. "Climate change: Second biennial report." Ottawa: Government of Canada.

Government of Canada. 2019. "Progress towards Canada's greenhouse gas emission reduction target. Canadian Environmental Sustainability Indicators.” Ottawa: Government of Canada.

2020. "Energy and the Economy." Accessed January 5, 2021. https://www.nrcan.gc.ca/science-data/data-analysis/energy-data-analysis/energyfacts/energy-and-economy/20062. 
Grande, Edgar, Tobias Schwarzbözl, and Matthias Fatke. 2019. "Politicizing immigration in Western Europe." Journal of European Public Policy 26 (10): 1444-1463. doi: 10.1080/13501763.2018.1531909.

Green, Jessica. 2019. "Why Canada needs a Green New Deal.” The Star, September 26, 2019. https://www.thestar.com/opinion/contributors/2019/09/26/why-canada-needs-a-green-newdeal.html.

Harvey, Fiona, and Jennifer Rankin. 2020. "What is the European Green Deal and will it really cost €1tn?" The Guardian, March 9, 2020.

https://www.theguardian.com/world/2020/mar/09/what-is-the-european-green-deal-andwill-it-really-cost-1tn?CMP=Share_iOSApp_Other.

Hoeglinger, Dominic. 2016. "The politicisation of European integration in domestic election campaigns." West European Politics 39 (1): 44-63. doi: 10.1080/01402382.2015.1081509.

Hutter, Swen, and Edgar Grande. 2014. "Politicizing Europe in the National Electoral Arena: A Comparative Analysis of Five West European Countries, 1970-2010.” Journal of Common Market Studies 52 (5): 1002-1018. doi: 10.1111/jcms.12133.

Ike, Vivian. 2020. "The Impact of Veto Players on Incremental and Drastic Policy Making: Australia's Carbon Tax Policy and Its Repeal." Politics \& Policy 48 (2): 232-264. doi: https://doi.org/10.1111/polp.12346.

Intergovernmental Panel on Climate Change (IPCC). 2018. "Global Warming of 1.5 degree." Summary for Policymakers. Geneva: IPCC.

Jänicke, Martin. 2012. "'Green Growth': From a Growing Eco-Industry to a Sustainable Economy.” Energy Policy 48: 13-21.

Joltreau, Eugénie, and Katrin Sommerfeld. 2019. "Why does emissions trading under the EU Emissions Trading System (ETS) not affect firms' competitiveness? Empirical findings from the literature." Climate Policy 19 (4): 453-471. doi: 10.1080/14693062.2018.1502145.

Julian, Peter. 2020. “A Green New Deal: Motion M-1,” Peter Julian, NDP. Accessed December 18, 2020. https://www.peterjulian.ca/in-the-house-motion-m-1-green-new-deal-for-canada.

Kellogg, Paul. 2015. "Prairie Capitalism Revisited: Canada, Bitumen, and the Resource Colony Question.” Journal of Canadian Studies 49 (3): 222-255. doi: 10.3138/jcs.49.3.222.

Kind, Ed. 2015. "Canada says it's 'back' on climate. But is it?" Climate Change News, November 20, 2015. Accessed February 18, 2021. https://www.climatechangenews.com/2015/11/29/canada-says-its-back-on-climate-but-isit/ 2015.

Klein, Naomi. 2019. The Burning Case for a Green New Deal. London: Allen Lane. 
Kuramochi, Takeshi, N. Nascimento, Maria Jose de Villafranca Casas, Hanna Fekete, Gustovo de Vivero, Swithin Lui, Marie Kurdziel, Mia Moisio, Paola Tanguy, Louise Jeffery, Tessa Schiefer, Masahiro Suzuki, N. Höhne, Heleen van Soest, Michel den Elzen, Kendall Esmeijer, Mark Roelfsema, Nicklas Forsell, and Mykola Gusti. 2019. "Greenhouse gas mitigation scenarios for major emitting countries. Analysis of current climate policies and mitigation commitments: 2019 update.” Cologne: New Climate Institute.

Löschel, Andreas. 2020. "European Green Deal und deutsche Energiewende zusammen denken!" Wirtschaftsdienst 100 (2): 78-79. doi: 10.1007/s10273-020-2566-X.

MacArthur, Julie L., Christina E. Hoicka, Heather Castleden, Runa Das, and Jenny Lieu. 2020. "Canada's Green New Deal: Forging the socio-political foundations of climate resilient infrastructure?" Energy Research \& Social Science 65: 101442. doi: https://doi.org/10.1016/j.erss.2020.101442.

MacDonald, Douglas, and Debora VanNijnatten. 2010. "Canadian climate policy and the North American influence.” In Borders and Bridges: Canada's policy relations in North America, edited by G.E. Hale and M. Gattinger, 177-193. Don Mills, ON: Oxford Univerity Press.

MacLean, Jason. 2018. "Paris and Pipeleines? Canada's Climate Policy Puzzle." Journal of Environmental Law and Practice 21 (1): 47-74.

MacNeil, Robert, and Matthew Paterson. 2016. "This changes everything? Canadian climate policy and the 2015 election." Environmental Politics 25 (3): 553-557. doi: 10.1080/09644016.2016.1140280.

Macunias, Silvia, and Géraud de Lassus Saint-Geniès. 2018. "The Evolution of Canada's International and Domestic Climate Policy: From Divergence to Consistency? Canada in International Law at 150 and Beyond," Paper no. 21. Waterloo: Centre for International Governance Innovation.

Marquardt, Jens. 2020. “Fridays for Future's Disruptive Potential: An Inconvenient Youth Between Moderate and Radical Ideas.” Frontiers in Communication 5 (48): 1-18.

McKibben, Bill. 2020. "When it comes to climate hypocrisy, Canada's leaders have reached a new low." The Guardian, February 5, 2020.

https://www.theguardian.com/commentisfree/2020/feb/05/when-it-comes-to-climatehypocrisy-canadas-leaders-have-reached-a-new-low?CMP=Share iOSApp_Other.

Meadowcroft, James. 2012. “Greening the State?” In Comparative Environmental Politics. Theory, Practice, and Prospects, edited by Paul F. Steinberg and Stacy D. VanDeveer, 6387. Cambridge, MA: MIT Press.

Mildenberger, Matto, and Erick Lachapelle. 2019. "Canadians in every riding support climate action, new research schows." The Conversation, September 5, 2019. Accessed January 4, 2021. https://theconversation.com/canadians-in-every-riding-support-climate-action-newresearch-shows-122918. 
Mitchell, Timothy. 2011. Carbon Democracy: Political Power in the Age of Oil. Brooklyn, NY: Verso.

Morris, Ian. 2015. Foragers, Farmers, and Fossil Fuels: How Human Values Evolve. New York, NY: Princeton University Press.

Oberthür, Sebastian. 2019. "Hard or Soft Governance? The EU's Climate and Energy Policy Framework for 2030.” Politics and Governance 7 (1): 17-27. doi: 10.17645/pag.v7i1.1796.

Oroschakoff, Kalina, and Karl Mathiesen. 2020. "How the EU's Green Deal survived the coronavirus pandemic." Politico, December 17, 2020. Accessed December 20, 2020. https://www.politico.eu/article/how-eu-climate-change-promises-survived-the-coronavirusplague/.

Pahle, Michael, Shonali Pachauri, and Karoline Steinbacher. 2016. "Can the Green Economy Deliver It All?: Experiences of renewable energy policies with socio-economic objectives.” Applied Energy 179: 1331-1341. doi: 10.1016/j.apenergy.2016.06.073.

Patterson, James T. 1969. The New Deal and the States: Federalism in Transition. Princeton, NJ: Princeton University Press.

Pettifor, Ann. 2019. The Case for the Green New Deal. London: Verso.

Pew Research Center. 2017. "Globally, People Point to ISIS and Climate Change as Leading Security Threats," Pew Research Center, August 1, 2017. https://www.pewresearch.org/global/2017/08/01/globally-people-point-to-isis-and-climatechange-as-leading-security-threats/.

Richards, John, and Leon Pratt. 1979. Prairie Capitalism: Power and influence in the new West. Toronto: McClelland and Stewart.

Rifkin, Jeremy. 2019. The Green New Deal: Why the Fossil Fuel Civilization will Collapse by 2028, and the Bold Economic Plan to Save Life on Earth. New York, NY: MacMillan.

Roger, Charles, Thomas Hale, and Liliana Andonova. 2017. "The Comparative Politics of Transnational Climate Governance." International Interactions 43 (1): 1-25. doi: 10.1080/03050629.2017.1252248.

Schattschneider, E. E. 1960. The Semi-Sovereign People: A Realist's View of Democracy in America. Hinsdale, IL: The Dyden Press.

Schreurs, Miranda A. 2011. "Federalism and the Climate: Canada and the European Union." International Journal: Canada's Journal of Global Policy Analysis 66 (1): 91-108. doi: 10.1177/002070201106600107.

Shields, Alexadre. 2019. "Un an après le Pacte, Dominic Champagne ne désespère pas." Le Devoir, November 8, 2019. https://www.ledevoir.com/societe/environnement/566585/unan-apres-le-pacte-de-la-transition. 
Skjærseth, Jon Birger. 2018. "Implementing EU climate and energy policies in Poland: Policy feedback and reform." Environmental Politics 27 (3): 498-518. doi: 10.1080/09644016.2018.1429046.

Smil, Vaclav. 2018. Energy and Civilization. Cambridge, MA: MIT Press.

Sovacool, Benjamin K., and Steve Griffiths. 2020. "The cultural barriers to a low-carbon future: A review of six mobility and energy transitions across 28 countries." Renewable and Sustainable Energy Reviews 119: 109569. doi: https://doi.org/10.1016/j.rser.2019.109569.

Sprinz, Detlef, and M. Weiß. 2001. "Domestic Politics and Global Climate Policy." In International Relations and Global Climate Change, edited by U. Luterbacher and Detlef Sprinz. Cambridge, MA: MIT Press.

Steffen, Will, Wendy Broadgate, Lisa Deutsch, Owen Gaffney, and Cornelia Ludwig. 2015. "The trajectory of the Anthropocene: The Great Acceleration." The Anthropocene Review 2 (1): 81-98. doi: 10.1177/2053019614564785.

Stephenson, J. R., B. K. Sovacool, and T. H. J. Inderberg. 2021. "Energy cultures and national decarbonisation pathways." Renewable and Sustainable Energy Reviews 137: 110592. doi: https://doi.org/10.1016/j.rser.2020.110592.

Stern, Nicholas. 2015. Why Are We Waiting? The Logic, Urgency, and Promise of Tackling Climate Change. Cambridge, MA: MIT Press.

Stoczkiewicz, Marcin. 2017. "EU should block Nord Stream 2 on climate grounds." Climate Home News. March 31, 2020.

Szarka, Joseph. 2016. "Towards an Evolutionary or a Transformational Energy Transition?: Transition Concepts and Roadmaps in European Union Policy Discourse." Innovation: The European Journal of Social Science Research 29 (3): 222-242. doi: 10.1080/13511610.2016.1166039.

Taylor, Kira. 2021. "European Central Bank sets up climate team, considers green bonds." EURACTIV, January 26, 2021. https://www.euractiv.com/section/energyenvironment/news/european-central-bank-sets-up-climate-team-considers-green-bonds/.

The Council of Canadians. 2019. "It's time for a Green New Deal," August, 2019. Accessed December 18, 2020. https://canadians.org/factsheet-greennewdeal.

The New Climate Economy. 2018. "Unlocking the Inclusive Growth Story of the 21st Century: Accelerating Climate Action in Urgent Times." Washington, DC: New Climate Economy.

Torney, Diarmuid. 2019. "Follow the leader? Conceptualising the relationship between leaders and followers in polycentric climate governance." Environmental Politics 28 (1): 167-186. doi: 10.1080/09644016.2019.1522029.

United Nations Environment (UNEP). 2011. "Towards a Green Economy: Pathways to Sustainable Development and Poverty Eradication." Nairobi: UNEP. . 2020. "The Emissions Gap Report 2020.” Nairobi: UNEP. 
Varoufakis, Yanis, and David Adler. 2020. "The EU's green deal is a colossal exercise in greenwashing." The Guardian, February 7, 2020.

https://www.theguardian.com/commentisfree/2020/feb/07/eu-green-deal-greenwashursula-von-der-leyen-climate?CMP=Share_iOSApp_Other.

Wettestad, Jørgen, and Torbjørg Jevnaker. 2019. "Smokescreen Politics? Ratcheting Up EU Emissions Trading in 2017." Review of Policy Research 36 (5): 635-659. doi: 10.1111/ropr.12345.

World Bank. 2019. "Report of the High-Level Commission on Carbon Pricing and Competitiveness." Washington, DC: World Bank.

Wurzel, Rüdiger K. W., James Connelly, and Duncan Liefferink. 2017. The European Union in International Climate Change Politics. Still Taking a Lead. Abingdon: Routledge. 
Published by the Centre for European Studies at Carleton University, Ottawa, Canada

Available online at: https://ojs.library.carleton.ca/index.php/CJERS/index

The Canadian Journal of European and Russian Studies (CJERS - formerly Review of European and Russian Affairs) is an open-access electronic academic peer-reviewed journal: articles are subject to double-blind peer-review. Topics relate to the European Union, its Member States, the former Soviet Union, and Central and Eastern Europe. The journal is published by the Centre for European Studies, an associated unit of the Institute of European, Russian and Eurasian Studies at Carleton University.

CJERS aims to provide an accessible forum for the promotion and dissemination of high quality research and scholarship.

\section{Contact:}

Carleton University

The Centre for European Studies

1103 Dunton Tower

1125 Colonel By Drive

Ottawa, ON K1S 5B6

Canada

Tel: +01 613 520-2600 ext. 3117; E-mail: CJERS@ @arleton.ca

\section{Creative Commons License}

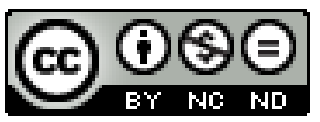

https://creativecommons.org/licenses/by-nc-nd/4.0/

This Working Paper is licensed under a Creative Commons Attribution-Non-CommercialNo Derivs 4.0 Unported License (CC BY-NC-ND 4.0).

Articles appearing in this publication may be freely quoted and reproduced, provided the source is acknowledged. No use of this publication may be made for resale or other commercial purposes.

ISSN: 2562-8429

(C) 2019 The Author(s) 